ACTA THERIOLOGICA

Vol. 27, 26: $377-384,1982$

\title{
Sex and Age Structure of a Forest Roe Deer Population under Hunting Pressure ${ }^{1}$
}

\author{
Bogusław FRUZIŃSKI \& Lesław ŁABUDZKI
}

\begin{abstract}
Fruziński B. \& Łabudzki L., 1982: Sex and age structure of a roe deer population under hunting pressure. Acta theriol., 27, 26: 377-384 [With 3 Tables \& 3 Figs.]

Studies were made from 1974-1979 of sex and age structure in a population of roe deer, Capreolus capreolus (Linnaeus, 1758) living in a wooded area about 8,000 ha in extent. The population was subject to fairly intensive utilization as game (from $12 \%$ to $23.5 \%$ ). The ratio of males to females in the population varied during the study period from $1: 1.2$ to $1: 2.5$, and was created chiefly by the effect of natural winter mortality. The age distribution of the population exhibited a decided predominance of faws (on an average about $42 \%$ of the population numbers) and a small proportion of animals from $1-3$ years old. It was found that utilization of does is random in character and is distributed proportionately over all age classes. The criteria applayed in Poland for selective shooting of bucks cause excessive shooting of individuals of medium age (3-5 years old).

[Dept. of Game Management, Academy of Agriculture, Wojska Polskiego 71d, 60-625 Poznań, Poland]
\end{abstract}

\section{INTRODUCTION}

Sex and age structure of a population under natural conditions is the resultant of the action of intrapopulation mechanisms, most often specific for the given species and habitat factors. It is the latter which cause mortality due to predators and to climatic conditions to be unequal in relation to sex and age of individuals (Petrusewicz, 1978). Sex and age structure are of decisive importance to the functioning of the population, and determine, inter alia, the extent of increase, spatial organization and even mortality indices. They are particularly important in the case of populations of species with a fairly long life cycle, such as the roe deer (Fruziński \& Łabudzki, 1982). Sex and age structure also act indirectly on the individual quality of animals, two of the manifestations of which are body weight and strength of antlers (Szczerbinski, 1964).

Under conditions of hunting management utilization of the population is of decisive importance as it may act selectively and consequently lead to disturbance of the population structure. It is relatively easy to

${ }^{1}$ Praca wykonana w ramach problemu MR-II/15 koordynowanego przez Instytut Ekologii Polskiej Akademii Nauk. 
shape sex ratio by appropriate shooting, but shaping the age structure in a roe deer population is difficult, owing to subjective criteria for estimating age of deer by hunters, particularly in relation to does, and on account of the specific criteria for selective shooting applying in Poland, which involve preferred utilization of certain age classes only of bucks.

The purpose of the study was to define sex and age structure in a roe deer population, Capreolus capreolus (Linnaeus 1758), in a large wooded area and to determine the effect exerted on these structures by the way in which the population is utilized for game purposes.

The studies were carried out from 1974-1980 at the Game Management Experimental Centre at Zielonka, belonging to the Academy of Agriculture in Poznan, and which includes a stretch of wooded land about 8000 ha in extent. Pinestands decidedly predominate there $(85.2 \%)$ often with an admixture of oak and partly uniform oakwoods (about $10 \%$ ). The distribution of biotopes and age classes of the treestands is also diversified (Fruziński, Łabudzki \& Wlazełko, 1983).

The numbers of roe deer in different years were determined by means of driving censuses (Pucek et al., 1975). A census of this kind was carried out twice a year, in spring and autumn.

\section{MATERIAL AND METHODS}

There is considerable difficulty in determining sex structure in the case of roe deer living in a forest habitat. Direct observations supply relatively little data and are extremely time-consuming, and the results they produce often depend on weather conditions, times of day and year, different sexual activity etc. It is therefore essential to obtain a very large amount of data in order to ensure that results are objective. Direct observations of roe deer were recorded on special cards, stating the sex of the animals observed, their exact localization, and date and hour of observation. Data were obtained on a total of 9,737 individuals (Table 1).

Use was also made of material obtained during driving censuses. Autumn drives were carried out at the beginning of November when the majority of the bucks still carry antlers. The observers were colleagues experienced in field work.

Many of the data were also supplied by observations of roe deer along lines transecting the forest, carried out systematically in a separate part of the range (Fruziński, Łabudzki \& Wlazełko, 1983). Assuming that shooting, at least in relation to females, is random, data obtained from shooting in different seasons were used to define age structure of the population. Age was defined on the basis of tooth wear in the mandibles collected (Rieck, 1970; Pielowski, 1970). Age was estimated for a total of 366 bucks and 327 does. Both the amount and intensity of utilization of these animals was carefully recorded in all seasons.

\section{RESULTS}

There were considerable fluctuations in sex structure during the study period, with more distinct stabilization in 1977 and 1978 (Table 1). As from the hunting season of 1974/75 the combined index of utilization 
of roe deer in the Zielonka range systematically increased, from about $12 \%$ to $23.5 \%$, of the spring numbers of the basic herd (Table 2), although this was not accompanied by clearly more intensive utilization of does. On an average during the course of 5 seasons the utilization of the two sexes was balanced: $38.6 \%$ of bucks, $38.2 \%$ of does and $23.2 \%$ of fawns (Table 3). There was, however, more intensive shooting of females in the fawn class, on an average level of about $75 \%$.

There has, however, been a decided shift in favour of females in the population during the last two years (Table 1), chiefly as the result of the severe and snowy winter of $1978 / 79$ and the administration order to cease shooting does during the $1979 / 80$ season.

There is distinct predominance of fawns in the population's age structure, and these, according to results obtained by driving, form $42 \%$ of the population numbers (Fruziński \& Eabudzki, 1982). Among the other age classes, the percentage of which in the population was determined by means of establishing the age of shot individuals, by far the largest number consists of animals of medium age $-3-5$ years old (Fig. 1), forming jointly $40.6 \%$ of the bucks and $36 \%$ or does.

Table 1

Sex composition of 9,737 roe deer observed over the period from $1974-1980$.

\begin{tabular}{cccc}
\hline Year & Males & Females & Sex ratio \\
\hline 1974 & 492 & 842 & $1: 1.7$ \\
1975 & 685 & 991 & $1: 1.4$ \\
1976 & 665 & 825 & $1: 1.2$ \\
1977 & 444 & 693 & $1: 1.5$ \\
1978 & 407 & 638 & $1: 1.5$ \\
1979 & 300 & 540 & $1: 1.8$ \\
1980 & 296 & 744 & $1: 2.5$ \\
Total & 3580 & 6157 & $1: 1.7$ \\
\hline
\end{tabular}

Table 2

Numbers and utilization of roe deer at Zielonka from 1974-1979.

\begin{tabular}{|c|c|c|c|c|c|c|c|c|c|}
\hline \multirow{2}{*}{$\begin{array}{l}\text { Hunting } \\
\text { season }\end{array}$} & \multicolumn{3}{|c|}{ Numbers in spring } & \multicolumn{3}{|c|}{$\begin{array}{l}\text { Numbers of } \\
\text { individuals shot }\end{array}$} & \multicolumn{3}{|c|}{$\begin{array}{c}\text { Exploitation } \\
\text { ratio, } \%\end{array}$} \\
\hline & M & $\mathbf{F}$ & & $\mathbf{M}$ & $\mathbf{F}$ & & M & $\mathbf{F}$ & \\
\hline $1974 / 5$ & 464 & 806 & 1270 & 59 & 92 & 151 & 12.7 & 11.4 & 11.9 \\
\hline $1975 / 6$ & 650 & 940 & 1590 & 91 & 104 & 195 & 14.0 & 11.0 & 12.3 \\
\hline $1976 / 7$ & 662 & 828 & 1490 & 104 & 82 & 186 & 15.7 & 9.9 & 12.5 \\
\hline $1977 / 8$ & 445 & 692 & 1137 & 117 & 151 & 268 & 26.2 & 21.8 & 23.6 \\
\hline $1978 / 9$ & 372 & 611 & 983 & 111 & 120 & 231 & 29.8 & 19.6 & 23.5 \\
\hline
\end{tabular}

3-Acta Theriologica 


\section{DISCUSSION}

The sex structure of the roe deer population is a variable value. Sex ratio is formed by, inter alia, the effect of the different natural mortality index of does and bucks, and of shooting. Habitat mechanisms are probably of particular importance, since even in a population not subject to hunting pressure at Kalø sex ratio was from $1: 1.8$ to $1: 2.2$ in favour of does (Strandgaard, 1972). In other roe deer populations also it exhibits predominance of females (Nikolandie, 1968; Prusaite et al., 1974).

Variations in sex structure at Zielonka were the result primarily of the effect of the habitat on the population during the winter period, since intensity of shooting was similar in relation to both male and female individuals (Table 2 and 3 ). Intensive utilization of female fawns (on an average $75 \%$ of animals shot in this age class) undoubtedly contributed to stabilization of sex structure on the level accepted by the authors, i.e., $1: 1.5$. The necessity for intensive utilization of females in order

Table 3

Utilization structure of the roe deer population at Zielonka from 1974-1979.

\begin{tabular}{|c|c|c|c|c|c|c|}
\hline \multirow{2}{*}{$\begin{array}{c}\text { Hunting } \\
\text { season }\end{array}$} & \multicolumn{2}{|c|}{ Bucks } & \multicolumn{2}{|c|}{ Does } & \multicolumn{2}{|c|}{ Fawns } \\
\hline & $\mathrm{N}$ & $\%$ & $\mathrm{~N}$ & $\%$ & $\mathrm{~N}$ & $\%$ \\
\hline $1974 / 5$ & 50 & 32.4 & 68 & 45.4 & 33 & 22.2 \\
\hline $1975 / 6$ & 69 & 35.4 & 71 & 36.4 & 55 & 28.2 \\
\hline $1976 / 7$ & 97 & 52.1 & 58 & 31.2 & 31 & 16.7 \\
\hline $1977 / 8$ & 90 & 33.6 & 109 & 40.7 & 69 & 25.7 \\
\hline $1978 / 9$ & 91 & 39.4 & 86 & 37.2 & 54 & 23.4 \\
\hline Mean & 79.4 & 38.6 & 78.4 & 38.2 & 48.4 & 23.2 \\
\hline
\end{tabular}

to achieve approximately balanced sex ratio is also due to certain intrapopulation mechanisms. Sex ratio among embryos at Zielonka was $1: 1.25$ in favour of females (Fruziński \& Łabudzki, 1982). In many European populations sex ratio during embryonic development and in newborn fawns is, however, more or less balanced (Borg, 1970; Kurt, 1968; Prior, 1968; Nikolandie, 1968; Strandgaard, 1972). This shows, that a tendency to maintain a balanced sex ratio is also more advantageous from the population aspect. The sex ratio of $1: 1$ recommended in hunting practice is, however, difficult to obtain, not only from population aspect but also as the result of the effect of the habitat. At Zielonka sex structure was distinctly shifted in favour of females as the result of the severe and snowy winter of $1978 / 79$, when natural mortality was about $32.3 \%$ (Fruziński \& Łabudzki, 1982) and, according to data which have not as yet been sufficiently documented, applied to a greater 
degree to males than females. Borg (1970) also observed greater natural mortality among males, although his explaining this by the reproductive behaviour of males does not seem convincing.

Intrapopulation and habitat factors determine whether maintainance of balanced sex structure requires more intensive utilization of the fameales.

On account of methodical difficulties there are not many source data on the age composition of roe deer populations, and the age pyramids most frequently given for game management planning are usually theoretical in character and very regular in shape. As the result of unequal natural mortality and shooting in different age classes the representation of these classes in the population is not equal.

Decidedly the most numerous age class consists of individuals below one year of age (fawns), which in 1950 in Denmark formed approximately $50 \%$ of the autumn population numbers, a complete sample having been taken by means of total elimination of roe deer by shooting

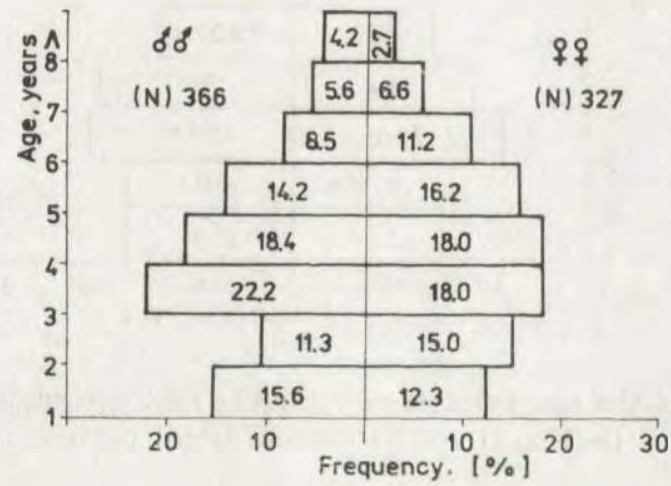

Fig. 1. Sex and age pyramid of the roe deer population at Zielonka.

(Andersen, 1953). Under Danish conditions also, in a population in no way subjected to hunting pressure, fawns formed about $34.3 \%$ (from 16 to $47 \%$ ) of the autumn population numbers (Strandgaard, 1972). At Zielonka the youngest age class formed on an average $42 \%$ of the population (from 38 to $48.5 \%$ ).

Apart from fawns the most numerous group consists of individuals from 3-5 years old, in the case of both females and males (Fig. 1). The percentage of animals $1-3$ years old is relatively small, which may be due to higher natural mortality, with simultaneous fairly considerable utilization of fawns for game purposes. The proportion of animals $2-3$ years old is also small in the population exempt from 
hunting exploitation, which at Kalø was $12 \%$ in the case of does and $10 \%$ for bucks (Strandgaard, 1972).

Shooting of females was planned and carried out entirely at random, without any attempt at selecting age classes. The right part of the age pyramid (Fig. 1) probably reflects the factual representation of natural conditions is formed primarily under the influence of climatic factors and predator pressure and is also distinguished by highest mortality in the youngest age classes. In populations living in extreme climates it is usual to have a small percentage of young animals, e.g. according to Blusma (1974), in Lithuania the roe deer population consisted of $34.5 \%$ fawns, $7.3 \%$ individuals $1 \frac{1}{2}$ years old and $58.2 \%$ of older roe deer.

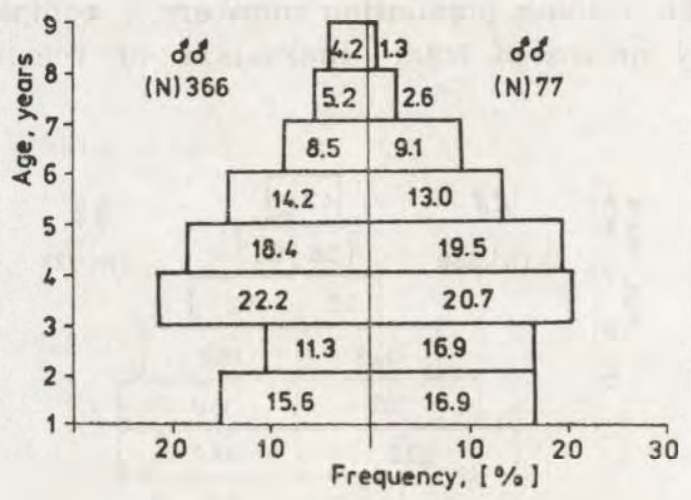

Fig. 2. Comparison of the age pyramid of roebucks shot according to selective rules (left part) and at random (right part).

Even in a mild climate and without shooting (Kalø) the proportion of analogical age classes is similar, even though diversified in different years. In 1965 , for instance, there were $42 \%$ of fawns, $13 \%$ of animals $1^{1 / 2}$ years old and about $44 \%$ of older individuals of both sexes. The low percentage in the Zielonka population of females $1^{1 / 2}$ years old (Fig. 1) thus confirms certain population regularities and shows the suitability of the method for defining the population's age structure on the basis of analysis of the mandibles of shot animals, if this is random in character, as in the case of females. Shooting of bucks in hunting practice results to some extent in selective shooting of certain age classes. The youngest age classes, particularly those of animals $2-3$ years old, are clearly under-utilized, with simultaneous intensified utilization of bucks from $3-5$ years old (Fig. 1-3), and 
consequently the most productive part of the population is most intensively utilized. The causes of this state of affairs are subjective in character. The large strong antlers in bucks of this age, with simultaneous frequent occurrence of some anomalies in antlers, makes such trophies attractive, whereas poorly developed antlers and the small body of the youngest bucks discourage hunters from shooting them.

When shooting was consistently carried out at random in part of the range of 77 males (every buck encountered was shot regardless of the quality of its antlers), this resulted in increased utilization of the youngest age classes (Fig. 2).

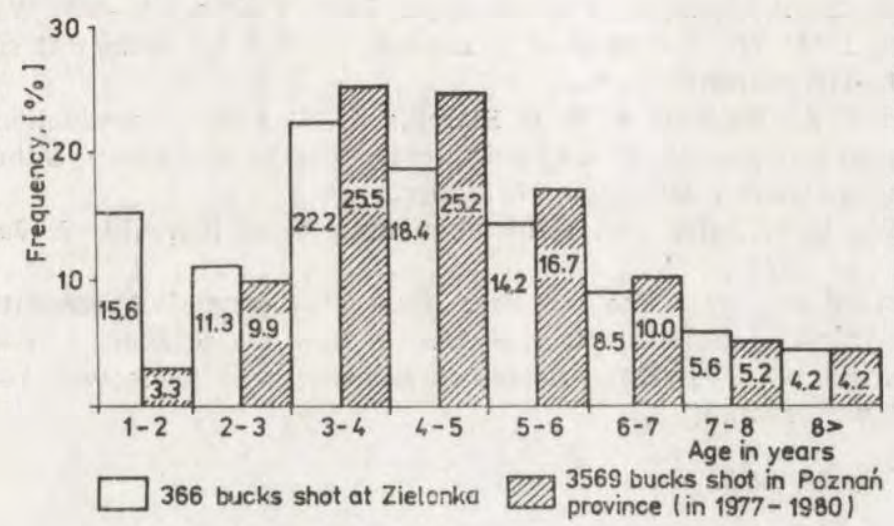

Fig. 3. Comparison of the age distribution of roebucks shot in the Poznan voivodship from 1977-1980 in accordance with selective rules, and roebucks shot at Zielonka.

Strict observance of the criteria applying to selective shooting has a selective effect on the population, as is shown by the age structure of 3,569 bucks shot from 1977-1979 in the Poznan voivodship in comparison with the age of bucks shot at Zielonka (Fig. 3). This is proof of the fact that the principles for selective shooting of bucks currently in force are not entirely sound, since they disturb the proper age structure of population as the result of excessive utilization of the medium age classes.

\section{REFERENCES}

1. Andersen J., 1953: Analysis of a Danish Roe Deer. Danish Rev. Game Biol., 2: $127-155$

2. Blusma P. P., 1974: Sexual differences and age changes of the weight and body size in Capreolus capreolus L. (Cervidae) in Lithuanian SSR. Ist. Intern. Theriol. Congress: 75. Moskva. 
3. Borg K., 1970: On mortality and reproduction of roe deer in Sweden during the period 1948-1969. Swedish Wildlife, 7: 121-149.

4. Fruziński B. \& Eabudzki L., 1982: Demographic processes in the forest roe deer population. Acta theriol., 27: 365-375.

5. Fruziński B., Łabudzki L. \& Wlazełko M., 1983: Habitat, density and spatial structure of the forest roe deer population. Acta theriol., 28:

6. Kurt E., 1968: Das Sozialverhalten des Rehwildes. Mammalia depicta, 4: 1-102. Paul-Parey. Hamburg-Berlin.

7. Nikolandie D., 1968: Okologische Charakterisistik der Rehpopulation in Distrikt Belje. Jeln. Beogard, 7: 73-95.

8. Petrusewicz K., 1978: Osobnik, populacja, gatunek. Państw. Wyd. Nauk: 1-384. Warszawa.

9. Pielowski Z., 1970: Sarna. Państw. Wyd. Roln. i Leśne: 1-215. Warszawa.

10. Prior R., 1968: The roe deer of Cranborne Chase: An ecological survey. Univ. Press: 1-119. Oxford, London.

11. Prusaite J. A., Blaschis A. S. \& Blaschis R. N., 1974: Reproduction intensivity and population growth in Capreolus capreolus L. (Cervidae) Lithuanian SSR. I-st. Intern. Theriol, Congress, 87. Moskva.

12. Rieck W., 1970: Alter und Gebissabnutzung beim Rehwild. Z. Jagdwiss., 16: $1-6$.

13. Strandgaard H., 1972: The roe deer (Capreolus capreolus) population at Kalø and the factors regulating its size. Danish Rev. Game Biol., 7: 1-205.

14. Szczerbiński W., 1964: Kilka zagadnień nowoczesnego łowiectwa: 1-133. Skrypty WSR w Poznaniu.

Accepted, July 29, 1982.

Bogusław FRUZIŃSKI i Lesław ŁABUDZKI

\section{WPEYW ŁOWIECKIEGO UŻYTKOWANIA NA STRUKTURĘ PECI I WIEKU} POPULACJI SARNY LESNEJ

\section{Streszczenie}

W ośrodku ,Zielonka" analizowano w latach 1974-1979 strukturę płci i wieku populacji sarn, przy pozyskaniu od $12 \%$ do $23,5 \%$ (Tabele 2,3 ). Struktura płci zmieniała się od $1: 1,2$ do $1: 2,5$, na korzyść osobników żeńskich (Tabela 1) i zależna była głównie od naturalnej śmiertelności zimowej. Struktura pozyskania wynosiła: $38,2 \%$ kóz oraz $23,2 \%$ koźląt (Tabela 3). Odstrzał osobników żeńskich w klasie koźląt był wysoki, około $75 \%$. Rozkład wiekowy populacji wykazał przewagę koźląt (średnio około $42 \%$ jesiennego stanu) oraz nieliczną reprezentację 1-3 letnich (Ryc. 2, 3). Najliczniejszą grupą są osobniki 3-5 letnie (Ryc. 1). Stwierdzono, że pozyskanie kóz ma charakter losowy i rozkłada się na wszystkie klasy wieku. Natomiast obowiązujące w kraju kryteria odstrzału selekcyjnego kozłów powodują nadmierną eksploatację osobników średniowiekowych (Ryc. 2). 